\title{
Bush climate-change plan gets cool response
}

Kendall Powell, Washington

A plan proposed by the Bush administration to research climate change is as likely to obscure important questions on the subject as to answer them. Such was the prevailing view of scientists who met last week to discuss the project.

The meeting of 1,300 scientists and officials was held in Washington on 3-5 December to deliver feedback on the draft Climate Change Science Program, which was released by the Bush administration last month (see Nature 420, 110;2002).

The plan will direct the US government's \$1.7-billion annual research programme on climate change, but its critics say that it lacks the clear priorities and detailed objectives needed to drive the programme forward.

Jim Anderson, an atmospheric scientist at Harvard University, said the draft was filled with "generalizations" that would serve the interests of "neither the public nor the scientific community".

Some climate scientists, including Anderson, hope that administration officials will take note of the feedback from the meeting so that the final version of the plan, due to be published next April, will be more specific. But others fear that the administration has no real interest in supporting research that might highlight either the causes or the dangers of global climate change.

Specialists at the meeting who had been asked to review the plan said that its main elements — nine broad research programmes, plus some big initiatives such as a global climate observation system — might fail through a lack of clearly stated objectives.

The scientists also called for more research on the impact of climate change on specific regions of the United States, more study of the relationship between the water cycle and climate change, and more computer power for running climate models. But environmental groups dismissed the consultation exercise as window-dressing.

James Mahoney, director of the programme, which coordinates the research activities of 13 federal agencies, says that the final plan will accelerate federally sponsored research and focus it on key policy questions.

"It's difficult to provide political leaders with a mandate to give people medicine that will have major impacts — it's like asking, 'Who wants to raise taxes?'," says Mahoney, who is assistant secretary of commerce for oceans and atmosphere. He emphasizes the need to reduce the scientific uncertainties surrounding global warming so that policymakers can make better decisions.

The plan would allow for an extra $\$ 40$ million annual initiative to tackle three areas of uncertainty: the role of aerosols in climate change, the size and location of carbon sources and sinks in North America, and how natural feedback processes influence climate change.

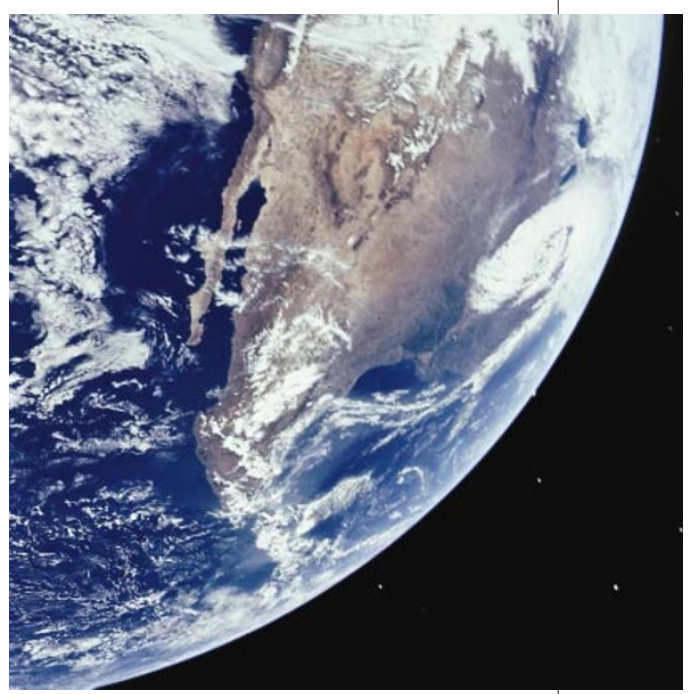

Clouded issue: can the United States' plan for climate research get to the heart of the problem?

But some observers question the plan's emphasis. "More research doesn't necessarily decrease uncertainty," says Benjamin Preston of the Pew Center on Global Climate Change. "And levels of uncertainty are not necessarily preventing decision-making right now."

Researchers are now hoping that Mahoney will produce a final version of the plan that is more to their liking.

www.climatescience.gov

\section{Safety panel backs principle of gene-therapy trials}

\section{Erika Check, Washington}

Clinical trials of a gene therapy for a rare disorder of the immune system should be allowed to continue in the United States, according to the panel that advises the National Institutes of Health (NIH) on the safety of gene transfer.

Regulators in five countries halted such studies earlier this year, after a French boy being treated for severe combined immunodeficiency disease (SCID) developed a leukaemia-like illness (see Nature 420, $116-118 ; 2002)$. Most researchers now agree the gene therapy was a cause of his cancer.

The US Food and Drug Administration (FDA) has been working with investigators to determine how the country's own trials could proceed. Many researchers are now calling for extra precautions to check for cancer in certain patients undergoing gene therapy.

The NIH's Recombinant DNA Advisory Committee (RAC), which met in Bethesda, Maryland, on 4-6 December, recommended that the US trials should proceed with appropriate monitoring and informed consent. But the RAC deferred any rulings on monitoring patients after such trials.

Scientists suspect that the retrovirus vector used to deliver the genetic material to the French patient caused his cancer. But the RAC did not comment on any US genetherapy trials using retroviruses apart from those to treat SCID. It is still unclear how the FDA will deal with the other studies.

Current NIH guidelines do not require researchers conducting gene-therapy trials to follow their patients' health for any set period of time. But the FDA has already told investigators that they should make plans to follow their patients long after the studies are over. At least one scientist running a SCID gene-therapy trial told the RAC that he has been advised by the FDA to plan on tracking his patients for the rest of their lives.

RAC member David Sidransky, a cancer geneticist at Johns Hopkins University School of Medicine in Baltimore, says that it would be expensive and impractical to require more than a handful of investigators to undertake life-long monitoring. He adds that two of the
French boy's close relatives had childhood cancers, so he may have inherited a genetic defect that raises his risk of developing cancer.

"The question is would I rather spend $\$ 100$ million on monitoring, when we may not see another leukaemia in the next 100 years, or would I rather spend \$100 million treating sick patients," Sidransky says. "I'm not ready to commit to a major monitoring programme based on information from one patient."

Theodore Friedmann, a gene-therapy researcher at the University of California, San Diego, and chair of the RAC, says that the committee will take up the issue at its next meeting in March, and then draw up guidelines on how researchers should monitor their subjects. The FDA is expected to take the RAC's recommendations into consideration as it decides what to require from scientists who want to conduct genetransfer studies in the future. "I hope that the language we come up with will be relevant not just to SCID, but to gene-transfer trials more generally," Friedmann says. 